\title{
Approved LXR agonists exert unspecific effects on pancreatic $\beta$-cell function
}

\author{
Jonas Maczewsky $^{1} \cdot$ Julia Kaiser $^{1} \cdot$ Peter Krippeit-Drews $^{1} \cdot$ Gisela Drews $^{1}$
}

Received: 16 October 2019 / Accepted: 24 February 2020 / Published online: 7 March 2020

(c) The Author(s) 2020

\begin{abstract}
Novel agonists of the nuclear liver-X-receptor (LXR) are designed to treat metabolic disorders or cancer. The rationale to develop these new drugs is based on promising results with established LXR agonist like T0901317 and GW3965. LXR $\alpha$ and LXR $\beta$ are expressed in $\beta$-cells, and expression is increased by T0901317. The aim of the present study was to evaluate whether effects of these drugs on $\beta$-cell function are specific and reliably linked to LXR activation. T0901317 and GW3965, widely used as specific LXR agonists, show rapid, non-genomic effects on stimulus-secretion coupling of mouse pancreatic $\beta$-cells at low $\mu \mathrm{M}$ concentrations. T0901317 lowered the cytosolic $\mathrm{Ca}^{2+}$ concentration, reduced or completely inhibited action potentials, and decreased insulin secretion. GW3965 exerted similar effects on insulin secretion. T0901317 affected the production of reactive oxygen species and ATP. The involvement of the classical nuclear LXRs in T0901317- and GW3965-mediated effects in $\beta$-cells could be ruled out using $\operatorname{LXR} \alpha, \operatorname{LXR} \beta$ and double knockout mice. Our results strongly suggest that LXR agonists, that are considered to be specific for this receptor, interfere with mitochondrial metabolism and metabolism-independent processes in $\beta$-cells. Thus, it is indispensable to test novel LXR agonists accompanying to ongoing clinical trials for acute and chronic effects on cell function in cellular systems and/or animal models lacking classical LXRs.
\end{abstract}

Keywords Stimulus-secretion coupling $\cdot$ Cytosolic $\mathrm{Ca}^{2+}$ concentration $\cdot$ Insulin secretion $\cdot$ LXR $\cdot$ T0901317 $\cdot$ GW3965

\section{Introduction}

The liver-X-receptor (LXR) is known to influence cholesterol and lipid metabolism in the liver [1,2]. The classical subtypes LXR $\alpha$ and LXR $\beta$ mediate their effects as nuclear receptors [3]. During the last decade, several effects of LXR on other organs e.g. muscle, adipose tissue and hypothalamus and mitochondria were reported which are important players in the regulation of glucose metabolism (for review see [4]). Besides this, the capability of LXR ligands to influence the concentration of reactive oxygen species (ROS) and to reduce endoplasmic reticulum stress opens new application spectra for LXR agonists particularly against metabolic diseases [5-7]. The suggested pathways are diverse and include cytosolic signal cascades [8], and/or changes in gene expression [9]. In obese animal models of

Gisela Drews

gisela.drews@uni-tuebingen.de

1 Institute of Pharmacy, Department of Pharmacology, University of Tübingen, Auf der Morgenstelle 8, 72076 Tübingen, Germany diabetes LXR activation by synthetic agonists improves insulin sensitivity and glucose tolerance [10-12]. The effects were contributed to interference with different pathways in liver, muscle and adipose tissue. In contrast, a study with mice fed a normal diet revealed that T0901317 application in vivo impairs glucose metabolism by decreasing glucose sensitivity and insulin secretion [13]. The findings are not supported by a study with LXR $\beta$-deficient mice: $\operatorname{LXR} \beta^{-1-}$ mice on low and high fat diet show improved glucose tolerance while $\operatorname{LXR} \beta^{-/-}$mice on a standard chow are glucose intolerant [14].

A few studies have tested effects of LXR activation on $\beta$-cell function and survival. One study reports that GW3965 protects human islets in vitro against inflammation [15]. The authors suggest LXR activation as a strategy for improving post-transplant islet survival. Another paper shows that T0901317 can protect human, mouse and rat $\beta$-cells against palmitate-induced toxicity [16]. Stearoyl-CoA desaturase (SCD) activation seems to be crucial in this cytoprotective effect. Mice lacking $\mathrm{LXR} \alpha$ or LXR $\beta$ elicit reduced SCD expression. Accordingly, they are more prone to palmitate toxicity. One study with human islets and another one with rat $\beta$-cells and MIN6 cells observe increased insulin secretion 
after LXR activation with T0901317 or GW3965 [17, 18]. The effects are contributed to interaction with enzymes involved in lipid metabolism. In contrast, Meng et al. demonstrate that T0901317 leads to $\beta$-cells dysfunction. They show with mouse $\beta$-cells and MIN6 cells reduced insulin secretion in response to LXR activation accompanied by decreased oxygen consumption, ATP production and current through L-type $\mathrm{Ca}^{2+}$ channels [13].

All these in vivo and in vitro studies were long-term studies with the LXR agonists T0901317 or GW3965. Possible acute or non-LXR-mediated effects were not considered in these studies.

Recently, we showed activation of a non-genomic rapid pathway by $10 \mu \mathrm{M}$ T0901317 that negatively influenced insulin secretion in murine and human pancreatic $\beta$-cells [19]. The LXR agonist interfered with stimulus-secretion coupling (SSC) by inhibiting the ATP synthesis probably due to effects on the ROS concentration [19]. In the present study, we challenge the assumption that effects of T0901317 or GW3965 can reliably be attributed to LXR activation. Our results question the specificity of the socalled LXR agonists that provide the basis for the development of novel drugs.

\section{Research design and methods}

\section{Cell and islet preparation}

Details are described in [20]. In brief, mouse islets were isolated by injecting collagenase $(0.5-1 \mathrm{mg} / \mathrm{ml})$ into the pancreas, and by handpicking after digestion at $37^{\circ} \mathrm{C}$. Male and female wild type $\mathrm{C} 57 \mathrm{Bl} / 6$ mice were used in equal shares. Development of mice with general ablation of LXR $\alpha$ and LXR $\beta$ are described in [21]. All LXR knockout $\left(\mathrm{LXR}^{-1-}\right.$ ) mice are on a $\mathrm{C} 57 \mathrm{Bl} / 6$ background and were housed under same conditions. Mice were bred in the animal facility of the Department of Pharmacology at the University of Tübingen. Principles of laboratory animal care (NIH publication no. 85-23, revised 1985) and German laws were followed. Mouse islets were dispersed to single cells and cell clusters, respectively, by trypsin treatment.

\section{Solutions and chemicals}

Recordings of the cytosolic $\mathrm{Ca}^{2+}$ concentration $\left(\left[\mathrm{Ca}^{2+}\right]_{\mathrm{c}}\right)$ were performed with a bath solution which contained $(\mathrm{mM})$ : $140 \mathrm{NaCl}, 5 \mathrm{KCl}, 1.2 \mathrm{MgCl}_{2}, 2.5 \mathrm{CaCl}_{2}$, glucose as indicated, 10 HEPES and $\mathrm{pH} 7.4$ adjusted with $\mathrm{NaOH}$. Same bath solution was used for determination of the mitochondrial membrane potential $(\Delta \Psi)$, ROS and membrane potential $\left(\mathrm{V}_{\mathrm{m}}\right)$ measurements in the perforated-patch configuration. The bath solution was modified by adding $0.1 \%$ bovine serum albumin (BSA) and used as incubation medium for ATP measurements. Krebs-Ringer-HEPES (KRH) solution for measurements of insulin secretion was composed of $(\mathrm{mM}): 120 \mathrm{NaCl}, 4.7 \mathrm{KCl}, 1.1 \mathrm{MgCl}_{2}$, $2.5 \mathrm{CaCl}_{2}$, glucose as indicated, $10 \mathrm{HEPES}, 0.5 \% \mathrm{BSA}$ and pH 7.4 adjusted with $\mathrm{NaOH}$. Pipette solution for measurements of $\mathrm{V}_{\mathrm{m}}$ consisted of $(\mathrm{mM}): 10 \mathrm{KCl}, 10 \mathrm{NaCl}$, $70 \mathrm{~K}_{2} \mathrm{SO}_{4}, 4 \mathrm{MgCl}_{2}, 2 \mathrm{CaCl}_{2}, 10$ EGTA, $20 \mathrm{HEPES}, 0.27$ amphotericin $\mathrm{B}$ and $\mathrm{pH}$ adjusted to 7.15 with $\mathrm{KOH}$. Islet cell clusters and pancreatic islets were cultured in RPMI 1640 (11.1 mM glucose) enriched with $10 \%$ foetal calf serum (FCS) and 1\% penicillin/streptomycin.

T0901317 and GW3965 were obtained from Biomol (Hamburg, Germany). Fura-2-AM was purchased from Biotrend (Köln, Germany) and 25-OH cholesterol from Santa Cruz (Heidelberg, Germany). Rhodamine 123 (Rh123), RPMI 1640 medium, FCS, penicillin/streptomycin, 2',7'dichlorodihydrofluorescein-diacetate (DCDHF-DA), dihydroethidium (DHE), ATP determination kit and trypsin were from Invitrogen (Karlsruhe, Germany). All other chemicals were purchased from Sigma (Taufkirchen, Germany) or Merck (Darmstadt, Germany) in the purest form available.

\section{Measurement of $\left[\mathrm{Ca}^{2+}\right]_{c}$}

Details are described in [20]. In brief, cells were loaded with $5 \mu \mathrm{M}$ Fura-2-AM for $35 \mathrm{~min}$ at $37^{\circ} \mathrm{C}$. The fluorescence was excited at $340 \mathrm{~nm}$ and $380 \mathrm{~nm}$ and the emission was measured. $\left[\mathrm{Ca}^{2+}\right]_{\mathrm{c}}$ was calculated according to an in vitro calibration. The maximum amplitude of $\mathrm{Ca}^{2+}$ oscillations $\left(\max .\left[\mathrm{Ca}^{2+}\right]_{c}\right)$ was taken to compare $\left[\mathrm{Ca}^{2+}\right]_{\mathrm{c}}$ under different experimental conditions.

\section{ATP measurement}

Details are described in [19]. 20 islets were kept for 30 min at $37^{\circ} \mathrm{C}$ in incubation medium under conditions as indicated. After cell lyses by adding a solution containing $200 \mathrm{mM}$ $\mathrm{NaOH}$ and $0.5 \mathrm{mM}$ EDTA, ATP concentration was elicited by the ATP determination kit according to manufactures instructions. Bioluminescence was determined with Luminometer 1253 (Bioorbit, Turku, Finland) in triplicate. Data were normalised to control condition under $15 \mathrm{mM}$ glucose.

\section{Patch-clamp measurements}

$\mathrm{V}_{\mathrm{m}}$ measurements were recorded with an EPC-9 patch-clamp amplifier using Patchmaster software (HEKA, Lambrecht, Germany) with the perforated-patch configuration in the current clamp mode at a holding current of $0 \mathrm{~mA}$. For determination of $\mathrm{V}_{\mathrm{m}}$ average plateau potential was evaluated 1 min before solution change. The same time interval was used for determination of action potential frequency. 


\section{Insulin secretion}

Details for steady-state incubations are described in [20]. Briefly, batches of five islets in triplicate were incubated in $1 \mathrm{ml} \mathrm{KRH}$ for $1 \mathrm{~h}$ at $37{ }^{\circ} \mathrm{C}$ under conditions as indicated. In experiments in which acute effects were investigated, the agonists were only present during the $1 \mathrm{~h}$ secretion measurement. To determine chronic effects, the agonists were absent during the $1 \mathrm{~h}$ secretion phase but the islets were preincubated for $72 \mathrm{~h}$ with agonists as indicated. Insulin was determined by radioimmunoassay (Merck Millipore, Darmstadt, Germany) with rat insulin as standard.

\section{Measurements of $\Delta \Psi$}

$\Delta \Psi$ was measured as Rh123 fluorescence (arbitrary units (a.u.) at $480 \mathrm{~nm}$ excitation wave length as described elsewhere [22]. To evaluate the effects, the values were averaged over $150 \mathrm{~s}$ at the end of each interval, i.e. before solution change.

\section{Measurement of ROS}

ROS production was measured using the fluorescent dyes DCDHF-DA and DHE. In the cells DCDHF-DA is oxidised to the fluorescent $2^{\prime}, 7^{\prime}$-dichlorofluorescein (DCF), which detects $\mathrm{H}_{2} \mathrm{O}_{2}$ and other ROS species. DHE is oxidised to 2hydroxyethidium $\left(2-\mathrm{OH}-\mathrm{E}^{+}\right)$, which mainly indicates $\mathrm{O}_{2}{ }^{-}$ formation. After $1 \mathrm{~h}$ incubation under conditions as indicated, the islet cell clusters were loaded for $15 \mathrm{~min}$ with $20 \mu \mathrm{M}$ DCDHF-DA and $10 \mu \mathrm{M}$ DHE, respectively. Fluorescence was excited at $480 \mathrm{~nm}$ and the intensity of the emitted light (arbitrary units (a.u.) was measured.

\section{Statistics}

Each series of experiments was performed with islets or islet cell clusters from at least three different mice. Means \pm SEM are given for the indicated number of experiments (islet cell clusters or islets). Statistical significance of differences was assessed by a paired Student's $t$ test. Multiple comparisons were made by repeated ANOVA followed by the Student-Newman-Keuls test. $P$ values $\leq 0.05$ were considered significant.

\section{Results}

\section{LXR agonists acutely affect SSC in $\beta$-cells}

Recently, we made the unexpected observation that $10 \mu \mathrm{M}$ T0901317 exerts acute effects on SSC in $\beta$-cells [19]. Thus, in a first approach we investigated effects of lower concentrations of T0901317 on $\beta$-cell function, which are most likely more specific for the LXR, and compared it to another drug which is assumed to be a specific LXR ligand, GW3965. One micromolar T0901317 reduced the frequency of action potentials (Fig. 1a, b). GW3965 $(1 \mu \mathrm{M})$ mimicked this effect on $\mathrm{V}_{\mathrm{m}}$ (Fig. 1c, d). As expected from these observations, acute administration of T0901317 $(1 \mu \mathrm{M}$ and $3 \mu \mathrm{M})$ and GW3965 $(0.3 \mu \mathrm{M}$ and $1 \mu \mathrm{M})$, respectively, inhibited glucosestimulated insulin secretion (Fig. 1e, f). Metabolic integrity of the $\beta$-cells is shown by increased insulin secretion at stimulating glucose concentration $(15 \mathrm{mM})$ compared with a substimulatory concentration $(3 \mathrm{mM})$.

\section{Chronic administration of LXR agonists inhibits insulin secretion}

In the literature effects of LXR agonists are described solely after chronic administration. Therefore, we performed insulin secretion experiments after $72 \mathrm{~h}$ pre-incubation with the same agonists that showed acute effects. Although, no agonists were present during the $1 \mathrm{~h}$ secretion measurement, glucose-stimulated insulin secretion was decreased after pre-incubation with T0901317 and GW3965 (Fig. 2a, b). Remarkably, acute and chronic administration of the drugs revealed comparable effects.

\section{T0901317 influences ATP synthesis and ROS production}

The SSC in $\beta$-cells is triggered by ATP synthesis due to redox processes within mitochondria. Increasing the glucose concentration from 0.5 to $15 \mathrm{mM}$ led to enhanced DCF fluorescence (mainly $\mathrm{H}_{2} \mathrm{O}_{2}$ production) in islet cell clusters. Administration of T0901317 in the presence of $15 \mathrm{mM}$ glucose resulted in a massive reduction of DCF-detectable ROS. (Fig. 2c). In contrast, enhancing the glucose concentration from 0.5 to $15 \mathrm{mM}$ reduced $2-\mathrm{OH}-\mathrm{E}^{+}$-detectable ROS (mainly $\mathrm{O}_{2}^{-}$) while T0901317 provoked an increase of $2-\mathrm{OH}-\mathrm{E}^{+}$-detectable oxidants at high glucose concentration. Likewise, ATP concentration under high glucose condition measured in intact islets was critically reduced by T0901317 (Fig. 2e). Metabolic integrity was shown by increased ATP concentration at stimulating glucose concentration $(15 \mathrm{mM})$ compared with a sub-stimulatory concentration $(3 \mathrm{mM})$.

\section{LXR agonists interfere with metabolism- independent processes}

The effects of the LXR agonists on ATP and ROS production point to interference with mitochondrial metabolism. We evaluated whether the agonists could also influence mitochondria-independent $\beta$-cell stimulation by arginine or GLP-1. Figure $3 \mathrm{a}-\mathrm{c}$ shows that arginine as well as GLP-1 strongly attenuated the inhibiting effect of $1 \mu \mathrm{M}$ T0901317 and $1 \mu \mathrm{M}$ GW3965, respectively. However, in 


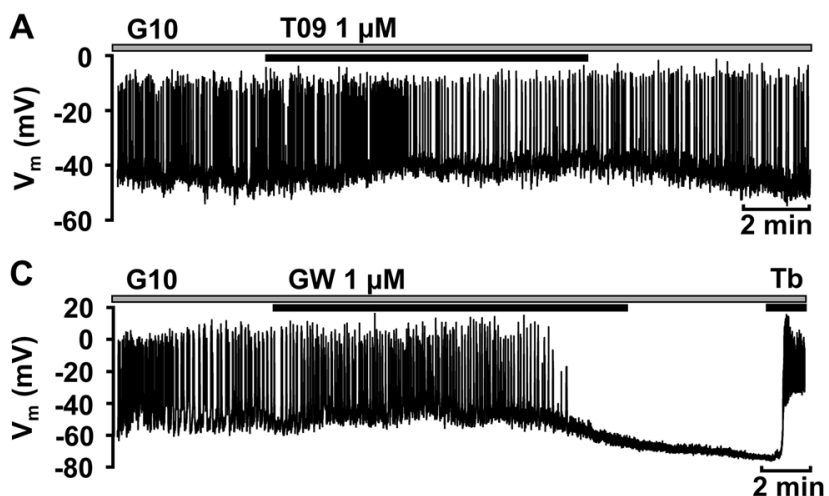

B

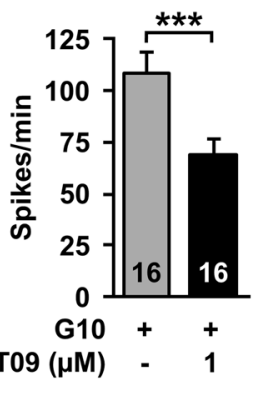

D

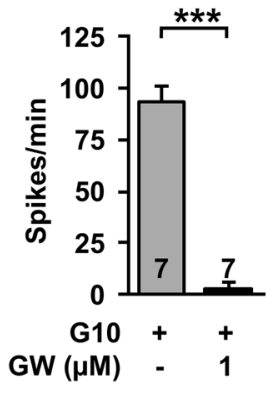

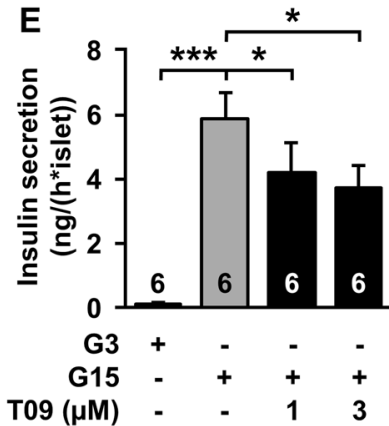

Fig. 1 LXR agonists acutely inhibit stimulus-secretion coupling in wild type $\beta$-cells. a Representative recording of $\mathrm{V}_{\mathrm{m}}$ with administration of T0901317 (T09). b Summary of all experiments. $n=16$. c Representative recording of $\mathrm{V}_{\mathrm{m}}$ with administration of GW3965 (GW). Tolbutamide $(\mathrm{Tb})$ was given at the end of the experiment to test whether closure of $\mathrm{K}_{\mathrm{ATP}}$ channels is still possible. $\mathbf{d}$ Summary of all

the presence of higher concentrations of the agonists $(10 \mu \mathrm{M})$ arginine or GLP-1 could not diminish the inhibitory effect of the drugs (Fig. 3d-f). Interestingly, even $30 \mathrm{mM}$ glucose could not hinder the strong depolarisation of $\Delta \Psi$ induced by $10 \mu \mathrm{M}$ T0901317 (Fig. 3g, h), which reflects inhibition of ATP production.

\section{LXR agonists acutely affect SSC in $\beta$-cells of $\mathbf{L X R}^{-/-}$ mice}

Similar effects of different LXR agonists suggest that the LXR is indeed targeted by the drugs. We tested the effects of T0901317 and GW3965 in $\beta$-cells isolated from $\mathrm{LXR} \beta^{-1-}$ mice. Both agonists decreased maximal $\left[\mathrm{Ca}^{2+}\right]_{\mathrm{c}}$ $\left(\max .\left[\mathrm{Ca}^{2+}\right]_{\mathrm{c}}\right.$ ) and $\mathrm{T} 0901317$ depolarised $\Delta \Psi$ under stimulating glucose condition (Fig. 4a-d). As the results did not show any impact of the $\mathrm{LXR} \beta^{--}$, the measurements were repeated with $\beta$-cells isolated from $\mathrm{LXR} \alpha^{-1-}$ mice. In $\mathrm{LXR}^{-1-} \beta$-cells T0901317 and GW3965 decreased max. $\left[\mathrm{Ca}^{2+}\right]_{\mathrm{c}}$ (Fig. 4e-g). Like the previous observation, T0901317 depolarised $\Delta \Psi$ in these knockout islet cell clusters (Fig. 4h). Accordingly, acute administration of T0901317 and GW3965 inhibited glucose-stimulated insulin secretion in pancreatic islets of $\mathrm{LXR} \alpha^{-/-}$and $\mathrm{LXR} \beta^{-/-}$

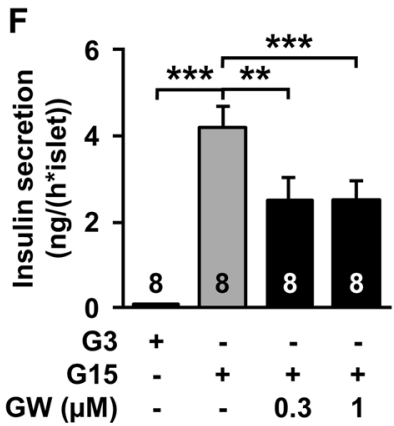

experiments. $n=7$. e Glucose-induced insulin secretion is reduced by T0901317 compared with control islets in the presence of $15 \mathrm{mM}$ glucose (G15). $n=6$. f GW3965 also decreased glucose-induced insulin secretion. $n=8$. Experiments were performed with different islet cell clusters or islets from $3-7$ mice. $* P \leq 0.05, * * P \leq 0.01$, $* * * P \leq 0.001$

mice, respectively (Fig. $4 \mathrm{i}, \mathrm{j}$ ). In these series of experiments we tested in addition the endogenous LXR agonist 25-OHcholesterol, which revealed similar results (Fig. 4i, j).

To exclude a possible compensation of LXR $\alpha$ or LXR $\beta$ by higher protein expression of the corresponding receptor in the respective knockout model, a double knockout mouse model with the concurrent deletion of LXR $\alpha$ and LXR $\beta$ was used. In $\beta$-cells of these mice the effect of T0901317 and GW3965 on max. $\left[\mathrm{Ca}^{2+}\right]_{\mathrm{c}}$ was still present (Fig. 5a-f). The higher concentration of T0901317 completely abolished glucose-dependent $\mathrm{Ca}^{2+}$ oscillations (Fig. 5b). The drop in $\left[\mathrm{Ca}^{2+}\right]_{\mathrm{c}}$ directly after removal of T0901317 points to ATPdependent SERCA activation after ATP depletion [19]. Accordingly, T0901317 depolarised $\Delta \Psi$ in $\mathrm{LXR} \alpha^{-1-} \beta^{-1-}$ islet cell clusters under high glucose condition (Fig. $5 \mathrm{~g}, \mathrm{~h}$ ).

\section{Discussion}

\section{Reputed LXR agonists acutely affect SSC by non- genomic actions}

Several studies show effects on metabolism after long exposure to reputed LXR agonists including T0901317 and 
A

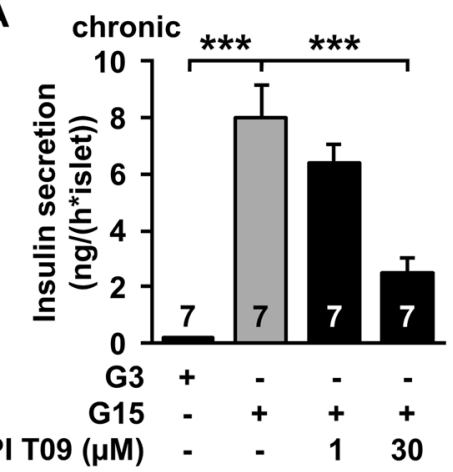

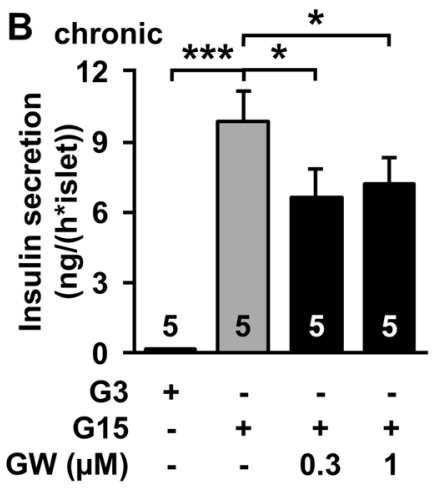

C

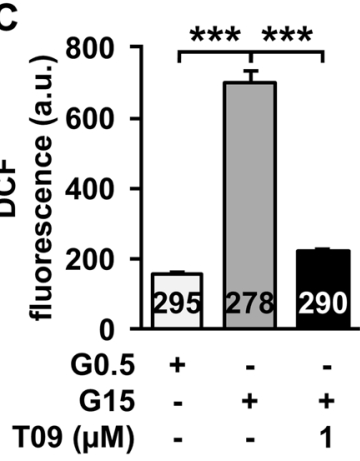

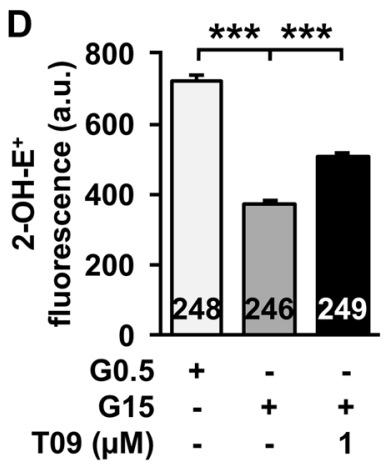

$\mathbf{E}$

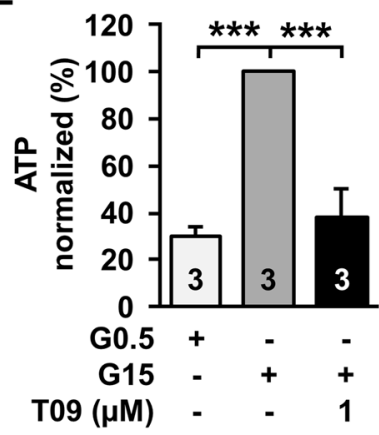

Fig. 2 LXR agonists influence $\beta$-cell metabolism. a Glucose-induced insulin secretion after $72 \mathrm{~h}$ pre-incubation (PI) with T0901317 compared with control conditions in the presence of $15 \mathrm{mM}$ glucose. T0901317 was not present during the $1 \mathrm{~h}$ of steady-state incubation for the determination of insulin secretion. $n=7$. b Glucose-induced insulin secretion after $72 \mathrm{~h}$ pre-incubation with GW3965. GW3965 was not present during the $1 \mathrm{~h}$ secretion measurement. $n=5$. c Measurement of DCF-detectable oxidants in islet cell clusters. Increasing the glucose concentration from 0.5 to $15 \mathrm{mM}$ leads to enhanced DCFfluorescence. Administration of T0901317 in the presence of $15 \mathrm{mM}$ glucose resulted in a massive reduction of DCF-detectable ROS. $n=278-295$. d Determination of $2-\mathrm{OH}-\mathrm{E}^{+}$-detectable oxidants in islet cell clusters. Increasing the glucose concentration from 0.5 to $15 \mathrm{mM}$ reduces the fluorescence. T0901317 leads to an increase of 2-OH-E ${ }^{+}$-detectable ROS at high glucose concentration. $n=246-249$. e Measurement of ATP concentration in intact islets. ATP content of islets is significantly reduced by T0901317 in comparison to control islets kept in $15 \mathrm{mM}$ glucose. $n=3$. Experiments were performed with different islet cell clusters or islets from $3-7$ mice. $* P \leq 0.05$, ***P $P \leq$ 0.001

receptor (ER) can translocate to the cell membrane, where it triggers rapid signalling [31, 32]. Moreover, 17 $\beta$-oestradiol can directly modify $\mathrm{K}_{\mathrm{ATP}}$ channel activity and interfere with the SUR1 channel subunit in $\beta$-cells [29, 33]. Furthermore, a rapid, cytosolic pathway that alters $\mathrm{K}_{\mathrm{ATP}}$ activity in $\beta$-cells is shown for the nuclear farnesoid-X-receptor [34].

\section{The classical nuclear LXR does not activate the acute pathway induced by T0901317 and GW3965 in $\beta$ - cells}

The role of LXRs in $\beta$-cell function is not completely understood. Data obtained with WT mouse or human islets in which synthetic LXR agonists have been used and LXRdeficient islets as well as in vivo and in vitro findings reveal many inconsistencies (see Introduction). There is not even unity whether LXR activation leads to stimulatory or inhibitory effects in vitro and to beneficial or detrimental effects in vivo. One reason for this complex situation may be that LXRs can exert opposite function in lean and obese 

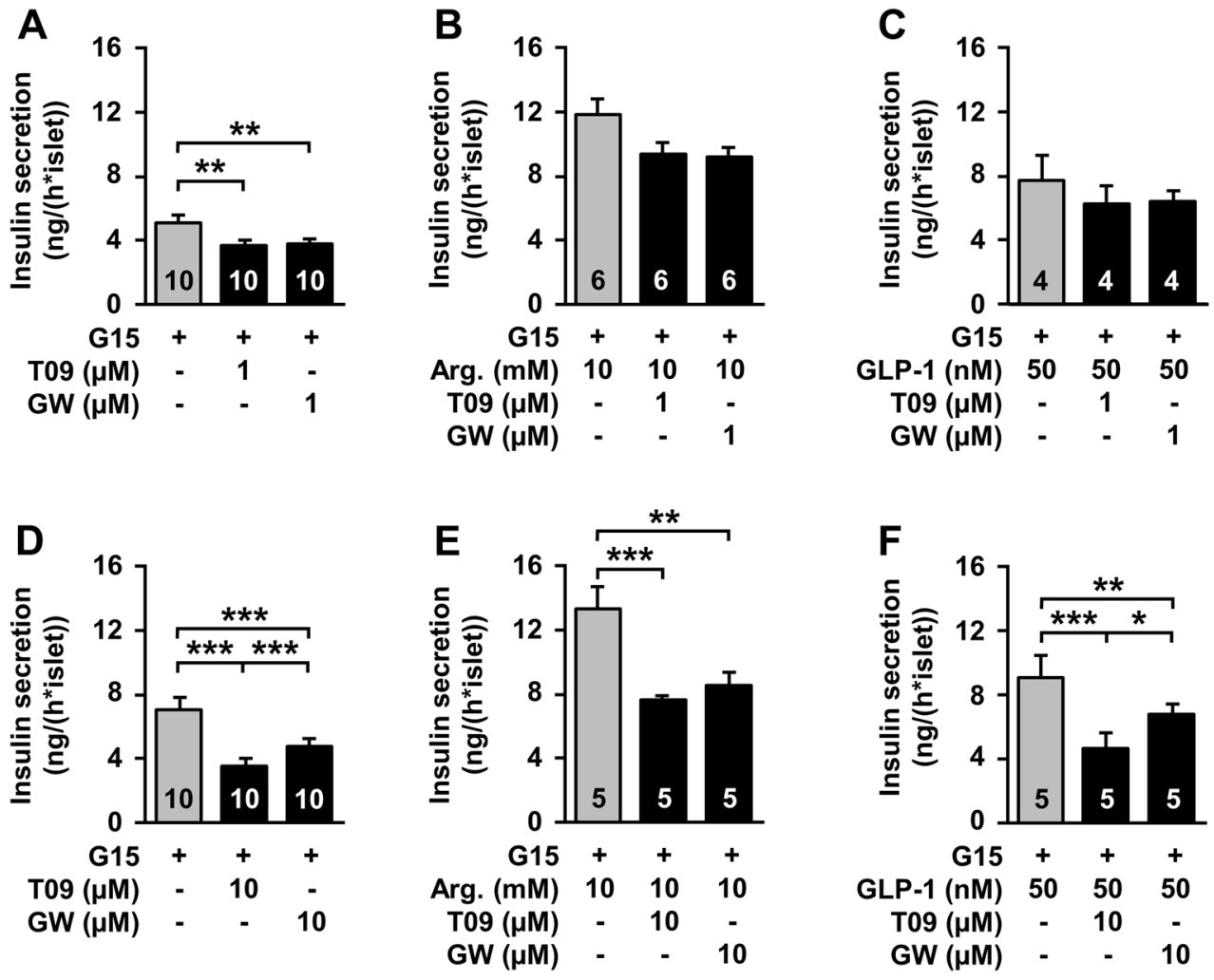

G

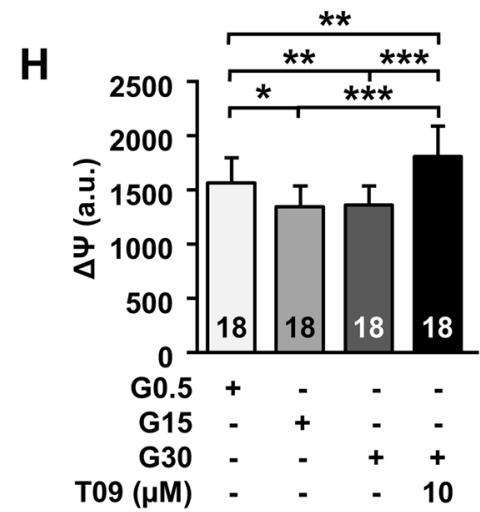

Fig. 3 LXR agonists exerts metabolism-independent effects. Influence of $1 \mu \mathrm{M}$ T0901317 (T09) and $1 \mu \mathrm{M}$ GW3965 (GW), respectively, on insulin secretion in the presence of $15 \mathrm{mM}$ glucose (a, control), $10 \mathrm{mM}$ arginine (b) and $50 \mathrm{nM}$ GLP-1 (c). $n=4-10$. The agonists had no significant effects in the presence of arginine or GLP-1. Inhibiting effect of $10 \mu \mathrm{M}$ T0901317 (T09) and $10 \mu \mathrm{M}$ GW3965 (GW), respectively, on insulin secretion in the presence of $15 \mathrm{mM}$ glucose (d, control), $10 \mathrm{mM}$ arginine (e) and $50 \mathrm{nM}$ GLP-1 (f). $n=5-10$.

animals, i.e. the function depends on the dietary state [14]. A similar function dependency on the nutritional situation has been described for the FXR earlier [35]. Another reason for contradictory findings may be the fact that synthetic LXR activators exert rapid, non-genomic, unspecific effects (see below).

We used $\mathrm{LXR}^{-1-}$ mice to evaluate the role of classical LXRs in the actions of the reputed LXR agonists. The ubiquitously identified LXR $\beta$ does not influence the acute
Administration of $10 \mu \mathrm{M}$ T0901317 on $\Delta \Psi$ in the presence of $30 \mathrm{mM}$ glucose still reveals a strong depolarisation. $\mathrm{g}$ Representative recording of $\Delta \Psi$ with administration of T0901317. Metabolic integrity is shown by a rapid depolarisation by $0.5 \mu \mathrm{M}$ FCCP. h Summary of all experiments. $n=18$. Experiments were performed with different islet cell clusters or islets from $3-10$ mice. $* P \leq 0.05$, $* * P \leq 0.01$, *** $P \leq$ 0.001

actions of LXR agonists in $\beta$-cells, shown by experiments with cells from LXR $\beta^{--}$mice. Compared with the LXR $\beta$, the LXR $\alpha$ seems to be less abundant in mouse islets and not detectable in $\beta$-cells [36]. We show that the $\alpha$-subtype also does not participate in the acute effects of GW3965 and T0901317 in $\beta$-cells. A third reputed LXR agonist, 25-OHcholesterol, which is believed to be the endogenous activator of the receptor also suppresses glucose-induced insulin secretion in both genotypes. 
A

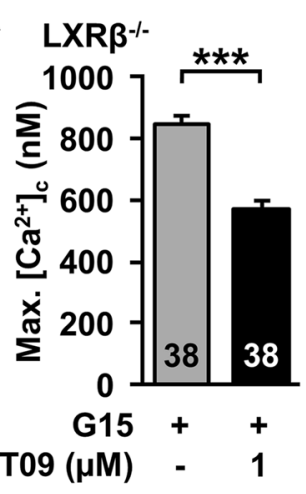

B

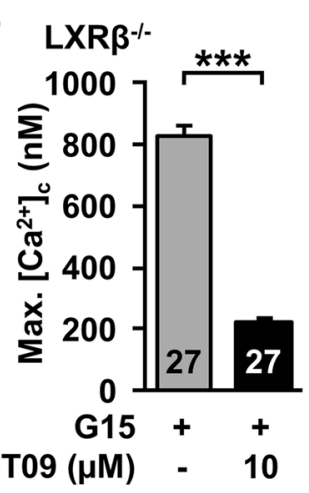

$\mathbf{E}$

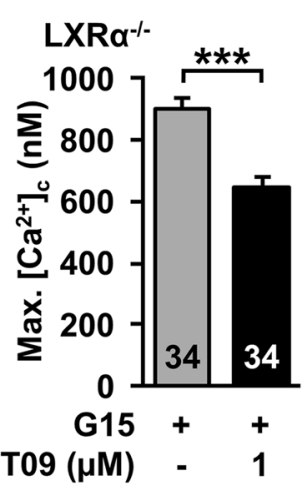

$\mathbf{F}$

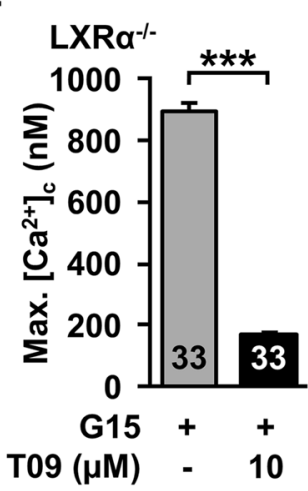

I

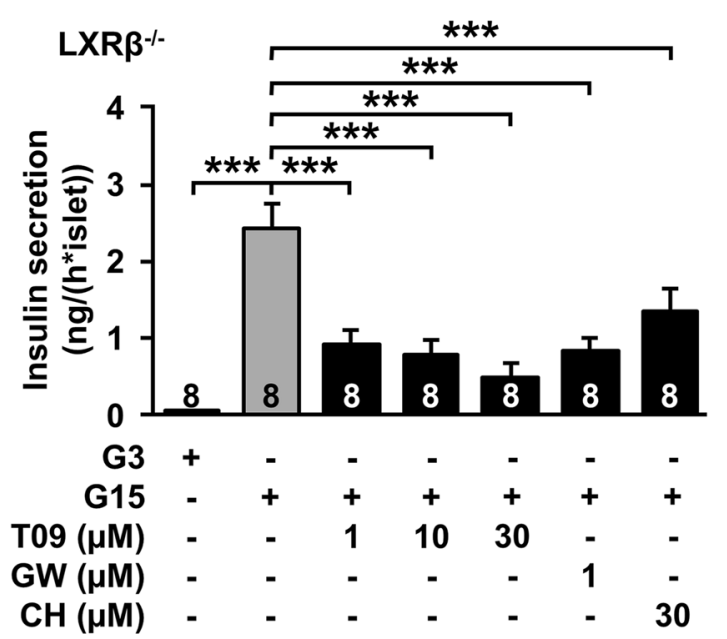

Fig. 4 Effects of LXR agonists are present in $\mathrm{LXR}^{-1-} \beta$-cells in the presence of $15 \mathrm{mM}$ glucose. a, b T0901317 $(1 \mu \mathrm{M}$ and $10 \mu \mathrm{M})$ reduce maximal $\left[\mathrm{Ca}^{2+}\right]_{\mathrm{c}}$ in $\beta$-cells of $\mathrm{LXR} \beta^{-1-}$ mice. $n=38$ and 27 . c $1 \mu \mathrm{M}$ GW3965 reduces maximal $\left[\mathrm{Ca}^{2+}\right]_{\mathrm{c}}$ in $\beta$-cells of $\mathrm{LXR} \beta^{-/-}$mice. $n=68$. d $10 \mu \mathrm{M}$ T0901317 depolarises $\Delta \Psi$ in islet-cell clusters of LXR $\beta^{-l-}$ mice. Metabolic integrity is shown by hyperpolarisation of $\Delta \Psi$ after changing the glucose concentration from 0.5 to $15 \mathrm{mM} . n=$ 47. e, f $1 \mu \mathrm{M}$ and $10 \mu \mathrm{M}$ T0901317 reduce maximal $\left[\mathrm{Ca}^{2+}\right]_{\mathrm{c}}$ in $\beta$-cells

To circumvent a possible counter-regulatory upregulation of LXR $\alpha$ in $L X R \beta^{-1-}$ cells and vice versa, cells from $\mathrm{LXR} \alpha^{-l-} \beta^{-1-}$ mice were used. Even in these cells,
C

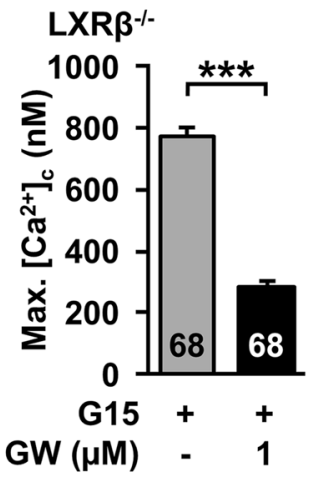

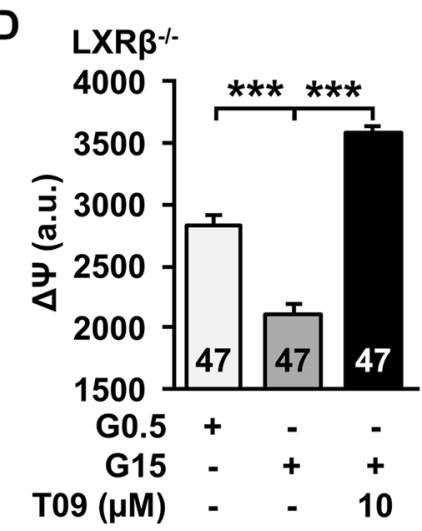
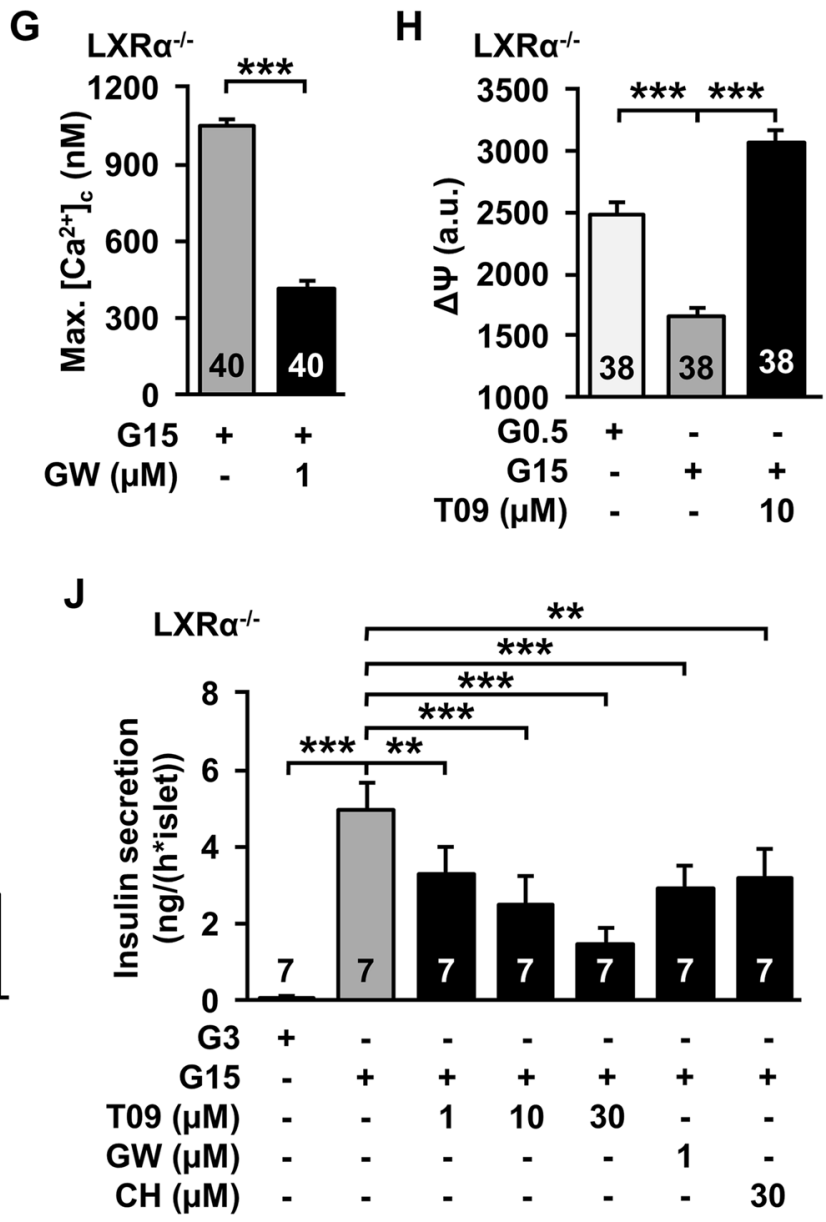

of LXR $\alpha^{-1-}$ mice. $n=34$ and 33. g $1 \mu \mathrm{M} \mathrm{GW} 3965$ reduces maximal $\left[\mathrm{Ca}^{2+}\right]_{\mathrm{c}}$ in $\beta$-cells of $\mathrm{LXR}^{-1-}$ mice. $n=40$. h $10 \mu \mathrm{M}$ T0901317 depolarises $\Delta \Psi$ in islet cell clusters of $\mathrm{LXR}^{-/-}$mice. $n=38$. $\mathbf{i}, \mathbf{j}$ Glucose-induced insulin secretion is reduced by T0901317, GW3965 and $25-\mathrm{OH}$-cholesterol $(\mathrm{CH})$ in islets from $\mathrm{LXR}^{-1-}$ and $\mathrm{LXR} \alpha^{-1-}$ mice. $n=8$ and 7. Experiments were performed with different islet cell clusters or islets from $3-8$ mice. $* * P \leq 0.01$, $* * * P \leq 0.001$

GW3965 and T0901317 exerted their inhibitory effects on SSC. The results clearly point to a mechanism independent of the classical LXRs. 


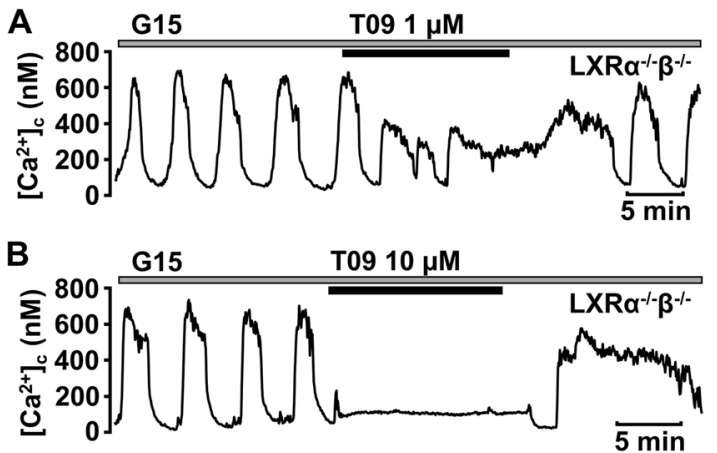

E
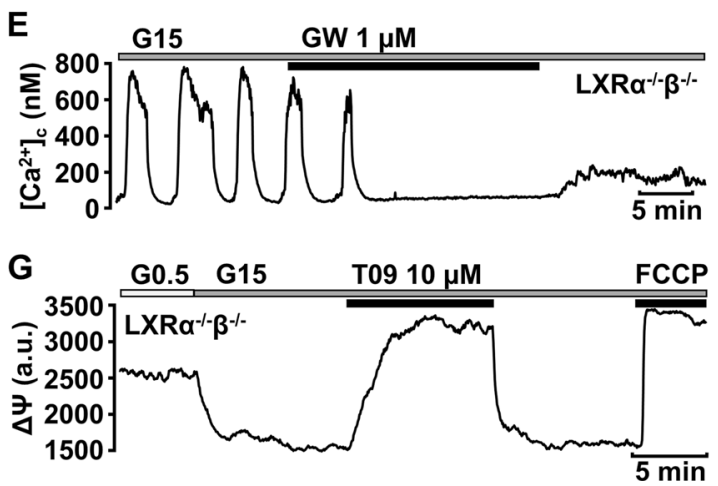

Fig. 5 Acute effects of LXR agonists are present in $\mathrm{LXR} \alpha^{-/-} \beta^{-1-}$ $\beta$-cells. a, b Representative measurements showing inhibition of glucose-induced oscillations of $\left[\mathrm{Ca}^{2+}\right]_{\mathrm{c}}$ by $1 \mu \mathrm{M} \mathrm{T} 0901317$ (a) and $10 \mu \mathrm{M}$ T0901317 (b) in the presence of $15 \mathrm{mM}$ glucose in $\beta$-cells of LXR $\alpha^{-1-} \beta^{-1-}$ mice. $\mathbf{c}, \mathbf{d} 1 \mu \mathrm{M}$ and $10 \mu \mathrm{M}$ T0901317 reduces maximal $\left[\mathrm{Ca}^{2+}\right]_{\mathrm{c}}$ in $\beta$-cells of $\mathrm{LXR \alpha ^{-1- }} \beta^{-1-}$ mice. $n=33$ and 36 . e Representative measurement showing inhibition of glucose-induced oscillations of $\left[\mathrm{Ca}^{2+}\right]_{\mathrm{c}}$ by $1 \mu \mathrm{M} \mathrm{GW} 3965$ in the presence of $15 \mathrm{mM}$ glucose in $\beta$-cells of LXR $\alpha^{-I-} \beta^{-/-}$mice. f $1 \mu \mathrm{M} \mathrm{GW} 3965$ reduces the maximal

The fact that three chemically different so-called LXR agonists act in an analogue manner suggests the presence of a different target with a binding profile like the classical LXR. The rapid effects, most likely evoked by cytosolic signal cascades, point to an action of this non-classical LXR at the membrane or in the cytosol. The paper of Meng et al. [13] and our studies (this and [19]) point to interaction with mitochondria i.e. changes in ROS production and ATP depletion as one possible mode of action in $\beta$-cells. The action of low concentrations of T0901317 and GW3965 could be counteracted by increasing insulin secretion with either arginine or GLP-1. This seems to be irrespective of the mechanism because arginine depolarises via influx of positive ions, and GLP-1 by stimulating the amplifying pathway via an increase of the cAMP concentration. The data suggest that low concentrations of the drugs can affect SSC beyond interference with mitochondrial metabolism. However, at higher concentrations $(10 \mu \mathrm{M})$ of the agonists, arginine and GLP-1 did not prevent the inhibitory effect any more suggesting that at this concentration the effect on mitochondrial metabolism prevails. This assumption is further supported by the fact that increasing the glucose
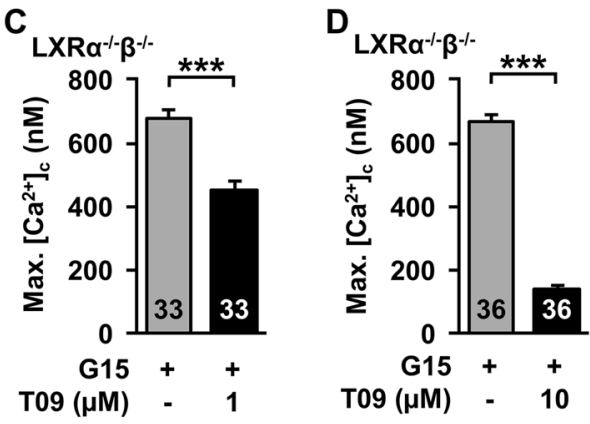

$\mathbf{F}$

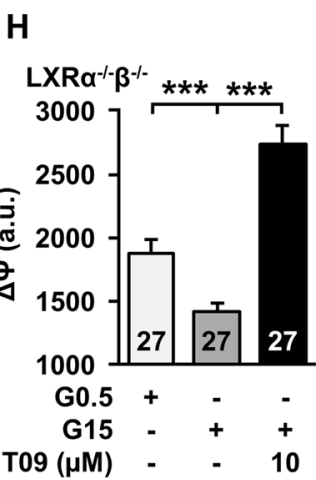

$\left[\mathrm{Ca}^{2+}\right]_{\mathrm{c}}$ in $\beta$-cells of $\mathrm{LXR} \alpha^{-1-} \beta^{-/-}$mice. $n=26$. g Representative measurement of $\Delta \Psi$ in islet cells of $\mathrm{LXR} \alpha^{-/-} \beta^{-/-}$mice. Increasing the glucose concentration from 0.5 to $15 \mathrm{mM}$ leads to hyperpolarization of $\Delta \Psi$ due to enhanced ATP production. Administration of T0901317 results in rapid and reversible depolarisation of $\Delta \Psi$. Metabolic integrity is shown by a rapid depolarisation by $0.5 \mu \mathrm{M}$ FCCP. $\mathbf{h}$ Summary of all experiments of this series. $n=27$. Experiments were performed with different islet cell clusters from three mice. $* * * P \leq$ 0.001

concentration to the maximal depolarising effect of glucose (30 mM) did not suppress the strong depolarisation of $\Delta \Psi$ provoked by $\mathrm{T} 0901317$.

The functionality of mitochondrial processes is essential in all organs and cell systems. Therefore, several effects attributed to LXR in different cell types may be caused by the interaction of LXR agonists with mitochondrial function. As a result, our data question conclusion about the involvement of LXR in physiological processes drawn from studies with T0901317 or GW3965 without use of LXRdeficient cell systems or mice.

\section{A word of caution}

Previous results of studies with established LXR ligands led to the development of new LXR agonists for therapeutic use in cancer and metabolic diseases. Very recently, it has been shown that LXR agonism by GW3965, and the novel LXR ligand RGX-104 enhances the activation of cytotoxic Tlymphocytes in mice and humans with cancer [37]. A clinical phase 1 study was accomplished with the LXR agonist BMS-852927 [38]. The authors draw the conclusion 
that BMS-852927 exerts beneficial effects on hypercholesterolaemia in humans by activation of the LXR. But they also observed adverse effects e.g. on lipogenesis and neutrophilic granulocytes in healthy volunteers questioning the therapeutic impact [38]. Another first-in-human study with the LXR ligand LXR-623 was performed with healthy participants to test a possible application of LXR agonists in the therapy of arteriosclerosis [39]. In this study, LXR-623 led to increased appearance of adverse events related to the central nervous system [39].

We show unspecific actions of well-established LXR agonists suggesting re-interpretation of previous results. The exact target mediating the observed rapid effects is still unknown. This leads to a more complex assessment of possible risk factors, and side effects of all LXR agonists. Thus, it is indispensable to intensify the research with potential new drugs with respect to acute, LXR-independent effects.

Acknowledgements We acknowledge the excellent and skilful technical assistance of Isolde Breuning. We are grateful to Jan Ake Gustafsson, Karolinska Institute, Sweden for providing the knockout mice. This work was supported by a grant from the DFG (G.D.). Open Access funding provided by Projekt DEAL.

Author contributions J.M. and J.K. researched data, wrote and edited the paper. P.K.-D. contributed to discussion and study design and edited the paper; G.D. designed the study, wrote and edited the paper, contributed to discussion, and is the guarantor of this study.

\section{Compliance with ethical standards}

Conflict of interest The authors declare that they have no conflict of interest.

Publisher's note Springer Nature remains neutral with regard to jurisdictional claims in published maps and institutional affiliations.

Open Access This article is licensed under a Creative Commons Attribution 4.0 International License, which permits use, sharing, adaptation, distribution and reproduction in any medium or format, as long as you give appropriate credit to the original author(s) and the source, provide a link to the Creative Commons license, and indicate if changes were made. The images or other third party material in this article are included in the article's Creative Commons license, unless indicated otherwise in a credit line to the material. If material is not included in the article's Creative Commons license and your intended use is not permitted by statutory regulation or exceeds the permitted use, you will need to obtain permission directly from the copyright holder. To view a copy of this license, visit http://creativecommons. org/licenses/by/4.0/.

\section{References}

1. D.J. Peet, S.D. Turley, W. Ma, B.A. Janowski, J.M. Lobaccaro, R. E. Hammer, D.J. Mangelsdorf, Cholesterol and bile acid metabolism are impaired in mice lacking the nuclear oxysterol receptor LXR alpha. Cell 93(5), 693-704 (1998)
2. B.A. Janowski, P.J. Willy, T.R. Devi, J.R. Falck, D.J. Mangelsdorf, An oxysterol signalling pathway mediated by the nuclear receptor LXR alpha. Nature 383(6602), 728-731 (1996). https:// doi.org/10.1038/383728a0

3. D.J. Peet, B.A. Janowski, D.J. Mangelsdorf, The LXRs: a new class of oxysterol receptors. Curr. Opin. Genet. Dev. 8(5), 571-575 (1998). https://doi.org/10.1016/s0959-437x(98)80013-0

4. K.R. Steffensen, J.A. Gustafsson, Putative metabolic effects of the liver X receptor (LXR). Diabetes 53(Suppl 1), S36-S42 (2004)

5. S. Ferderbar, E.C. Pereira, E. Apolinario, M.C. Bertolami, A. Faludi, O. Monte, L.E. Calliari, J.E. Sales, A.R. Gagliardi, H.T. Xavier, D.S. Abdalla, Cholesterol oxides as biomarkers of oxidative stress in type 1 and type 2 diabetes mellitus. Diabetes Metab. Res. Rev. 23(1), 35-42 (2007). https://doi.org/10.1002/ dmrr.645

6. L. Chang, Z. Zhang, W. Li, J. Dai, Y. Guan, X. Wang, Liver-Xreceptor activator prevents homocysteine-induced production of $\mathrm{IgG}$ antibodies from murine B lymphocytes via the ROS-NFkappaB pathway. Biochem. Biophys. Res. Commun. 357(3), 772-778 (2007). https://doi.org/10.1016/j.bbrc.2007.04.016

7. Q. He, J. Pu, A. Yuan, W.B. Lau, E. Gao, W.J. Koch, X.L. Ma, B. $\mathrm{He}$, Activation of liver-X-receptor alpha but not liver-X-receptor beta protects against myocardial ischemia/reperfusion injury. Circ. Heart Fail. 7(6), 1032-1041 (2014). https://doi.org/10.1161/ CIRCHEARTFAILURE.114.001260

8. Q. He, J. Pu, A. Yuan, T. Yao, X. Ying, Y. Zhao, L. Xu, H. Tong, B. He, Liver $X$ receptor agonist treatment attenuates cardiac dysfunction in type 2 diabetic $\mathrm{db} / \mathrm{db}$ mice. Cardiovascular Diabetol. 13 (1), 149 (2014). https://doi.org/10.1186/s12933-014-0149-0

9. Y. Dong, G. Gao, H. Fan, S. Li, X. Li, W. Liu, Activation of the liver X receptor by agonist TO901317 improves hepatic insulin resistance via suppressing reactive oxygen species and JNK pathway. PLoS ONE 10(4), e0124778 (2015). https://doi.org/10. 1371/journal.pone.0124778

10. M. Baranowski, P. Zabielski, A.U. Blachnio-Zabielska, E. Harasim, A. Chabowski, J. Gorski, Insulin-sensitizing effect of LXR agonist T0901317 in high-fat fed rats is associated with restored muscle GLUT4 expression and insulin-stimulated AS160 phosphorylation. Cell Physiol. Biochem. 33(4), 1047-1057 (2014). https://doi.org/10.1159/000358675

11. B.A. Laffitte, L.C. Chao, J. Li, R. Walczak, S. Hummasti, S.B. Joseph, A. Castrillo, D.C. Wilpitz, D.J. Mangelsdorf, J.L. Collins, E. Saez, P. Tontonoz, Activation of liver X receptor improves glucose tolerance through coordinate regulation of glucose metabolism in liver and adipose tissue. Proc. Natl. Acad. Sci. USA 100 (9), 5419-5424 (2003). https://doi.org/10.1073/pnas.0830671100

12. G. Cao, Y. Liang, C.L. Broderick, B.A. Oldham, T.P. Beyer, R.J. Schmidt, Y. Zhang, K.R. Stayrook, C. Suen, K.A. Otto, A.R. Miller, J. Dai, P. Foxworthy, H. Gao, T.P. Ryan, X.C. Jiang, T.P. Burris, P.I. Eacho, G.J. Etgen, Antidiabetic action of a liver $\mathrm{x}$ receptor agonist mediated by inhibition of hepatic gluconeogenesis. J. Biol. Chem. 278(2), 1131-1136 (2003). https://doi.org/10. 1074/jbc.M210208200

13. Z.X. Meng, Y. Yin, J.H. Lv, M. Sha, Y. Lin, L. Gao, Y.X. Zhu, Y. J. Sun, $X$. Han, Aberrant activation of liver $X$ receptors impairs pancreatic beta cell function through upregulation of sterol regulatory element-binding protein $1 \mathrm{c}$ in mouse islets and rodent cell lines. Diabetologia 55(6), 1733-1744 (2012). https://doi.org/10. 1007/s00125-012-2516-2

14. I. Gerin, V.W. Dolinsky, J.G. Shackman, R.T. Kennedy, S.H. Chiang, C.F. Burant, K.R. Steffensen, J.A. Gustafsson, O.A. MacDougald, LXRbeta is required for adipocyte growth, glucose homeostasis, and beta cell function. J. Biol. Chem. 280(24), 23024-23031 (2005). https://doi.org/10.1074/jbc.M412564200

15. H. Scholz, T. Lund, M.K. Dahle, J.L. Collins, O. Korsgren, J.E. Wang, A. Foss, The synthetic liver X receptor agonist GW3965 
reduces tissue factor production and inflammatory responses in human islets in vitro. Diabetologia 52(7), 1352-1362 (2009). https://doi.org/10.1007/s00125-009-1366-z

16. K.H. Hellemans, J.C. Hannaert, B. Denys, K.R. Steffensen, C. Raemdonck, G.A. Martens, P.P. Van Veldhoven, J.A. Gustafsson, D. Pipeleers, Susceptibility of pancreatic beta cells to fatty acids is regulated by LXR/PPARalpha-dependent stearoyl-coenzyme A desaturase. PLoS ONE 4(9), e7266 (2009). https://doi.org/10. 1371/journal.pone.0007266

17. T. Ogihara, J.C. Chuang, G.L. Vestermark, J.C. Garmey, R.J. Ketchum, X. Huang, K.L. Brayman, M.O. Thorner, J.J. Repa, R. G. Mirmira, C. Evans-Molina, Liver X receptor agonists augment human islet function through activation of anaplerotic pathways and glycerolipid/free fatty acid cycling. J. Biol. Chem. 285(8), 5392-5404 (2010). https://doi.org/10.1074/jbc.M109.064659

18. A.M. Efanov, S. Sewing, K. Bokvist, J. Gromada, Liver X receptor activation stimulates insulin secretion via modulation of glucose and lipid metabolism in pancreatic beta-cells. Diabetes $\mathbf{5 3}$ (Suppl 3), S75-S78 (2004)

19. J. Maczewsky, J. Sikimic, C. Bauer, P. Krippeit-Drews, C. Wolke, U. Lendeckel, W. Barthlen, G. Drews, The LXR ligand T0901317 acutely inhibits insulin secretion by affecting mitochondrial metabolism. Endocrinology 158(7), 2145-2154 (2017). https:// doi.org/10.1210/en.2016-1941

20. B. Gier, P. Krippeit-Drews, T. Sheiko, L. Aguilar-Bryan, J. Bryan, M. Düfer, G. Drews,, Suppression of $\mathrm{K}_{\mathrm{ATP}}$ channel activity protects murine pancreatic beta cells against oxidative stress. J. Clin. Investig. 119(11), 3246-3256 (2009). https://doi.org/10.1172/ JCI38817

21. S. Alberti, G. Schuster, P. Parini, D. Feltkamp, U. Diczfalusy, M. Rudling, B. Angelin, I. Bjorkhem, S. Pettersson, J.A. Gustafsson, Hepatic cholesterol metabolism and resistance to dietary cholesterol in LXRbeta-deficient mice. J. Clin. Investig. 107(5), 565-573 (2001). https://doi.org/10.1172/JCI9794

22. A. Edalat, P. Schulte-Mecklenbeck, C. Bauer, S. Undank, P. Krippeit-Drews, G. Drews, M. Düfer, Mitochondrial succinate dehydrogenase is involved in stimulus-secretion coupling and endogenous ROS formation in murine beta cells. Diabetologia $\mathbf{5 8}$ (7), 1532-1541 (2015). https://doi.org/10.1007/s00125-015-35779

23. M. Spyridon, L.A. Moraes, C.I. Jones, T. Sage, P. Sasikumar, G. Bucci, J.M. Gibbins, LXR as a novel antithrombotic target. Blood 117(21), 5751-5761 (2011). https://doi.org/10.1182/blood-201009-306142

24. A.J. Unsworth, A.P. Bye, D.S. Tannetta, M.J.R. Desborough, N. Kriek, T. Sage, H.E. Allan, M. Crescente, P. Yaqoob, T.D. Warner, C.I. Jones, J.M. Gibbins, Farnesoid X receptor and liver $\mathrm{X}$ receptor ligands initiate formation of coated platelets. Arterioscler. Thromb. Vasc. Biol. 37(8), 1482-1493 (2017). https://doi. org/10.1161/ATVBAHA.117.309135

25. S. Schaffer, R. Tandon, H. Zipse, W. Siess, A. Schmidt, J. Jamasbi, E. Karshovska, W. Steglich, R. Lorenz, Stereo specific platelet inhibition by the natural LXR agonist 22(R)-OH-cholesterol and its fluorescence labelling with preserved bioactivity and chiral handling in macrophages. Biochem. Pharm. 86(2), 279-285 (2013). https://doi.org/10.1016/j.bcp.2013.04.024

26. V. Derangere, A. Chevriaux, F. Courtaut, M. Bruchard, H. Berger, F. Chalmin, S.Z. Causse, E. Limagne, F. Vegran, S. Ladoire, B. Simon, W. Boireau, A. Hichami, L. Apetoh, G. Mignot, F. Ghiringhelli, C. Rebe, Liver $\mathrm{X}$ receptor beta activation induces pyroptosis of human and murine colon cancer cells. Cell Death Differ. 21(12), 1914-1924 (2014). https://doi.org/10.1038/cdd.2014.117

27. C. Rebe, V. Derangere, F. Ghiringhelli, Induction of pyroptosis in colon cancer cells by LXRbeta. Mol. Cell Oncol. 2(1), e970094 (2015). https://doi.org/10.4161/23723548.2014.970094
28. A.B. Ropero, B. Soria, A. Nadal, A nonclassical estrogen membrane receptor triggers rapid differential actions in the endocrine pancreas. Mol. Endocrinol. 16(3), 497-505 (2002)

29. S. Soriano, A.B. Ropero, P. Alonso-Magdalena, C. Ripoll, I. Quesada, B. Gassner, M. Kuhn, J.A. Gustafsson, A. Nadal, Rapid regulation of K(ATP) channel activity by 17 \{beta $\}$ estradiol in pancreatic \{beta\}-cells involves the estrogen receptor $\{$ beta $\}$ and the atrial natriuretic peptide receptor. Mol. Endocrinol. 23(12), 1973-1982 (2009). https://doi.org/10.1210/ me.2009-0287

30. C.M. Revankar, D.F. Cimino, L.A. Sklar, J.B. Arterburn, E.R. Prossnitz, A transmembrane intracellular estrogen receptor mediates rapid cell signaling. Science 307(5715), 1625-1630 (2005)

31. W.P. Wong, J.P. Tiano, S. Liu, S.C. Hewitt, C. Le May, S. Dalle, J.A. Katzenellenbogen, B.S. Katzenellenbogen, K.S. Korach, F. Mauvais-Jarvis, Extranuclear estrogen receptor- $\alpha$ stimulates NeuroD1 binding to the insulin promoter and favors insulin synthesis. Proc. Natl. Acad. Sci. 107(29), 13057-13062 (2010)

32. E.R. Levin, S.R. Hammes, Nuclear receptors outside the nucleus: extranuclear signalling by steroid receptors. Nat. Rev. Mol. Cell Biol. 17(12), 783-797 (2016). https://doi.org/10.1038/nrm.2016. 122

33. S. Ackermann, S. Hiller, H. Osswald, M. Lösle, A. Grenz, A. Hambrock, 17 $\beta$-Estradiol modulates apoptosis in pancreatic $\beta$-cells by specific involvement of the sulfonylurea receptor (SUR) isoform SUR1. J. Biol. Chem. 284(8), 4905-4913 (2009)

34. M. Düfer, K. Hörth, R. Wagner, B. Schittenhelm, S. Prowald, T.F. Wagner, J. Oberwinkler, R. Lukowski, F.J. Gonzalez, P. KrippeitDrews, G. Drews, Bile acids acutely stimulate insulin secretion of mouse beta-cells via farnesoid $\mathrm{X}$ receptor activation and K(ATP) channel inhibition. Diabetes 61(6), 1479-1489 (2012). https://doi. org/10.2337/db11-0815

35. B. Schittenhelm, R. Wagner, V. Kähny, A. Peter, P. KrippeitDrews, M. Düfer, G. Drews, Role of FXR in beta-Cells of Lean and Obese Mice. Endocrinology 156(4), 1263-1271 (2015). https://doi.org/10.1210/en.2014-1751

36. H. Zitzer, W. Wente, M.B. Brenner, S. Sewing, K. Buschard, J. Gromada, A.M. Efanov, Sterol regulatory element-binding protein 1 mediates liver $X$ receptor-beta-induced increases in insulin secretion and insulin messenger ribonucleic acid levels. Endocrinology 147(8), 3898-3905 (2006). https://doi.org/10.1210/en. 2005-1483

37. M.F. Tavazoie, I. Pollack, R. Tanqueco, B.N. Ostendorf, B.S. Reis, F.C. Gonsalves, I. Kurth, C. Andreu-Agullo, M.L. Derbyshire, J. Posada, S. Takeda, K.N. Tafreshian, E. Rowinsky, M. Szarek, R.J. Waltzman, E.A. McMillan, C. Zhao, M. Mita, A. Mita, B. Chmielowski, M.A. Postow, A. Ribas, D. Mucida, S.F. Tavazoie, LXR/ApoE activation restricts innate immune suppression in cancer. Cell 172(4), 825-840 e818 (2018). https://doi. org/10.1016/j.cell.2017.12.026

38. T.G. Kirchgessner, P. Sleph, J. Ostrowski, J. Lupisella, C.S. Ryan, X. Liu, G. Fernando, D. Grimm, P. Shipkova, R. Zhang, R. Garcia, J. Zhu, A. He, H. Malone, R. Martin, K. Behnia, Z. Wang, Y.C. Barrett, R.J. Garmise, L. Yuan, J. Zhang, M.D. Gandhi, P. Wastall, T. Li, S. Du, L. Salvador, R. Mohan, G.H. Cantor, E. Kick, J. Lee, R.J. Frost, Beneficial and adverse effects of an LXR agonist on human lipid and lipoprotein metabolism and circulating neutrophils. Cell Metab. 24(2), 223-233 (2016). https://doi.org/ 10.1016/j.cmet.2016.07.016

39. A. Katz, C. Udata, E. Ott, L. Hickey, M.E. Burczynski, P. Burghart, O. Vesterqvist, X. Meng, Safety, pharmacokinetics, and pharmacodynamics of single doses of LXR-623, a novel liver Xreceptor agonist, in healthy participants. J. Clin. Pharm. 49(6), 643-649 (2009). https://doi.org/10.1177/0091270009335768 